\title{
Aglomerasi Industri Pengolahan Di Wilayah Kabupaten Jember Tahun 2011-2015
}

\section{(Studi Kasus: Subsektor Industri Makanan, Minuman, dan Tembakau)}

\author{
(Agglomeration Industries In Jember District Year 2011-2015 \\ (Case Study: Subsector of Food, Beverage and Tobacco Industry)) \\ Yuli Wulandari, Endah Kurnia Lestari*, I Wayan Subagiarta \\ Jurusan Ilmu Ekonomi dan Studi Pembangunan, Fakultas Ekonomi dan Bisnis, Universitas Jember (UNEJ) \\ Jln. Kalimantan 37, Jember 68121 \\ E-mail: endahkurnia.feb@unej.ac.id
}

\begin{abstract}
Abstrak
Konsentrasi dari aktivitas ekonomi secara spasial terutama pada industri, telah menjadi fenomena menarik untuk dianalisis. Adanya spesialisasi produk pada suatu wilayah akan menyebabkan terjadinya konsentrasi spasial pada suatu industri yang merujuk pada dua macam eksternalitas ekonomi yaitu, penghematan lokalisasi dan penghematan urbanisasi yang biasa disebut agglomeration economics. Agglomeration economies muncul karena sebuah industri akan memilih tempat dimana tempat tersebut akan menjamin proses produksi dalam jangka waktu yang lama. Tujuan dari penelitian ini adalah mengidentifikasi besaran kekuatan aglomerasi pada subsektor industri makanan, minuman, dan tembakau di wilayah Kabupaten Jember. Populasi penelitian ini adalah kecamatan di Kabupaten Jember tahun 2011-2015. Metode pengumpulan data adalah metode dokumentasi yang bersumber dari BPS dan Disperindag Kabupaten Jember. Analisis yang digunakan adalah indeks Ellison Glaeser. Berdasarkan hasil analisis diketahui secara keseluruhan keempat kecamatan (Wuluhan,Ambulu, Rambipuji dan Kalisat) memiliki tingkat konsentrasi sedang, dimana wilayah yang terkonsentrasi tersebut terjadi karena adanya kekuatan aglomerasi (agglomerasi effect) pada masing-masing wilayah yang disebabkan oleh pengaruh eksternalitas berupa natural advantage dan knowledge spillover.
\end{abstract}

Kata kunci: Aglomerasi, Eksternalitas, Kluster, Spesialisasi.

\begin{abstract}
The concentration of economic activity in the world, has become an interesting phenomenon to be analyzed. The existence of a product program in a region will lead to cultural growth in a sustainable state on two kinds of economic externalities namely, localization economy and urbanization economy commonly called economic agglomeration. The agglomeration economy arises because an industry will choose the place where it will guarantee the production process for a long time. The purpose of this study is to identify the magnitude of agglomeration strength in the sub-sector of the food, beverage and tobacco industries in Jember district. The population of this research is the sub-district in Jember Regency. The method of acculating data used are doumentation comes from BPS and Disperindag Jember District. The analysis used is Ellison Glaeser index. Based on the results of the analysis, it is known that all four sub-districts (Wuluhan, Ambulu, Rambipuji and Kalisat) have moderate concentration levels, where concentrated areas occur because of the agglomeration power (agglomeration effect) in each region due to the influence of externalities in the form of natural advantages and knowledge spillover.
\end{abstract}

Keywords: Agglomeration, Eksternality, Cluster, Specialization.

\section{Pendahuluan}

Pembangunan ekonomi regional merupakan usaha dalam rangka sebagai penguatan daya saing ekonomi suatu daerah. Penguatan daya saing ini dapat dilihat dari potensi dan keunggulan sektor yang menjadi spesialisasi perekonomian dalam mendorong pertumbuhan wilayah. Salah satu upaya yang dapat dilakukan yaitu dengan mendorong pengembangan kegiatan industri sebagai kegiatan ekonomi utama (prime mover) yang dapat memberikan efek ganda (multiplier effect) terhadap tumbuhnya sektor-sektor lain. Laju pertumbuhan PDRB pada sektor industri di Kabupaten Jember memiliki kontribusi yang cukup besar. Visi dan tujuan dalam Rancangan Peraturan Daerah Rencana Tata Ruang Wilayah (RAPERDA RTRW) Kabupaten Jember menempatkan sektor industri sebagai sektor basis. Pembangunan sektor industri hampir selalu mendapat prioritas utama dalam rencana pembangunan negara-negara sedang berkembang. Hal ini dikarenakan sektor industri memiliki beberapa keunggulan dibandingkan sektor lain diantaranya nilai kapitalisasi modal yang tertanam sangat besar, kemampuan penyerapan tenaga kerja yang besar dan juga kemampuan dalam menciptakan nilai tambah (value added creation) dari setiap input atau bahan dasar yang diolah. Menurut Arsyad (1991) Pertumbuhan ekonomi jangka panjang di negara industri dan negara sedang berkembang menunjukan bahwa sektor industri secara umum tumbuh lebih cepat dibandingkan sektor pertanian.

Perkembangan sektor industri di Kabupaten Jember terus meningkat peningkatan signifikan terjadi pada industri kecil. Jumlah industri kecil yang awalnya berjumlah 37.302 pada tahun 2012, naik menjadi 40.792 di tahun 2014. Industri sedang juga mengalami peningkatan dari 2.423 pada tahun 2012 menjadi 2.738 pada tahun 2014. Sedangkan industri besar kurang mengalami perubahan yang sangat berarti,

* Corresponding author 
hanya mengalami pertumbuhan sebesar $1,03 \%$ pada tahun 2013 dan $1,11 \%$ pada tahun 2014 . Industri sebagai salah satu sektor yang menunjang pembangunan ekonomi suatu daerah. Pada pengembangan sektor industri, kebijakan yang berorientasi spasial dan regional merupakan salah satu faktor kunci yang dapat mendukung pemerintah pusat dan daerah dalam merumuskan dan mengimplementasikan kebijakan pembangunan (Kuncoro, 2002). Untuk mendorong spesialisasi produk serta meningkatkan efesiensi dan produktivitas dapat dilakukan dengan pendekataan cluster atau pendekatan konsentrasi spasial dalam kebijakan nasional maupun regional pada sektor industri.

Aliran klasik beranggapan bahwa konsentrasi aktivitas ekonomi secara spasial biasanya merujuk pada dua macam eksternalitas ekonomi yaitu, penghematan lokalisasi dan penghematan urbanisasi yang biasa disebut agglomeration economics. Selain itu, berkumpulnya perusahaan atau industri yang saling terkait akan dapat meningkatkan efisiensi dalam pemenuhan input yang terspesialisasi yang lebih baik dan lebih murah. Kegiatan industri pengolahan di wilayah Kabupaten Jember sejalan dengan fokus kegiatan ekonomi Master Plan Percepatan dan Perluasan Pembangunan Ekonomi Indonesia (MP3EI) koridor Jawa Timur dimana Kabupaten Jember terspesialisasi pada subsektor industri makanan, minuman dan tembakau. Pada lima tahun terakhir antara tahun 2010-2014 Industri makanan, minuman dan tembakau memberikan kontribusi yang signifikan terhadap pengembangan kegiatan industri di Kabupaten Jember ratarata sebesar $34,45 \%$ dari total pendapatan sektor industri.

Salah satu pendekatan terintegrasi yang dipandang sesuai dengan pengembangan kegiatan industri di Kabupaten Jember yaitu melalui pendekatan kelompok dan membangun jaringan usaha yang saling terkait antar industri dengan membangun iklim persaingan secara sehat. Studi pendekatan ini dikenal dengan aglomerasi yang menjelaskan bahwa konsentrasi kegiatan industri secara spasial muncul karena pelaku ekonomi berupaya mendapatkan penghematan aglomerasi baik karena membesarnya skala produksi, penghematan lokalisasi dan urbanisasi dengan mengambil lokasi yang berdekatan satu sama lain. Semakin teraglomerasi secara spasial suatu perekonomian, maka akan semakin meningkat pertumbuhannya. Penelitian ini akan mencoba menganalisis lokasi dan mengidentifikasi besaran kekuatan aglomerasi pada subsektor industri makanan, minuman, dan tembakau di wilayah kabupaten Jember dalam kurun waktu tahun 2011-2015.

\section{Metode}

\section{Design Penelitian}

Metode penelitian dirancang melalui langkah-langkah penelitian dari mulai operasionalisasi variabel, penentuan jenis dan sumber data, metode pengumpulan data atau survei, model penelitian diakhiri dengan merancang analisis data.

Dalam melakukan penelitian dibutuhkan adanya suatu metode, cara atau taktik sebagai langkah-langkah yang harus ditempuh oleh seorang peneliti dalam memecahkan suatu permasalahan untuk mencapai suatu tujuan. Adapun metode dalam penelitian adalah metode deskriptif kuantitatif.

\section{Jenis dan Sumber Data}

Penelitian ini menggunakan data sekunder dengan data panel berupa data statistik industri di Kabupaten Jember tahun 2011-2015, jumlah unit dan tenaga kerja subsektor industri makanan, minuman, dan tembakau di wilayah Kabupaten Jember tahun 2011-2015 serta jumlah penduduk dan luas area di Kecamatan dan Kabupaten Jember tahun 2011-2015. Data tersebut diperoleh dari Badan Pusat Statistik (BPS), dan Dinas Perindustrian dan Perdagangan (Disperindag) Kabupaten Jember.

\section{Populasi dan Sampel}

Penelitian ini dilakukan di Kabupaten Jember pada tahun 2011 sampai tahun 2015. Dengan konsentrasi pada beberapa kecamatan di kabupaten Jember

\section{Metode Analisis Data}

Dalam penelitian ini untuk memecahkan rumusan masalah kedua yaitu mengidentifikasi besarnya pengaruh aglomerasi pada subsektor industri makanan, minuman dan tembakau di wilayah Kabupaten Jember yang mendorong terjadinya konsentrasi spasial dapat digunakan alat analisis Indeks Ellison Glaeser. Indeks Ellison Gleaser ditunjukan untuk mengisolasi efek dari konsentrasi spasial. Terdapat beberapa model dalam analisis indeks Ellison Gleaser ini, diantaranya:

\section{Gini Lokasional}

Gini lokasional, menunjukan tingkat spesialisasi suatu sektor dan konsentrasi spasial antara beberapa wilayah.

$$
g_{E G}=\sum_{i=1}^{M}\left(S_{i}^{S}-X_{i}\right)^{2}
$$

Dimana:

$g_{E G}=$ Indeks Gini Lokasional

$S_{i}^{S} \quad=$ Kontribusi tenaga kerja subsektor $S$ di kecamatan $i$ terhadap tenaga kerja subsektor $S$ di Kabupaten

Jember

$X_{i}=$ Kontribusi tenaga kerja industri pengolahan kecamatan $i$ terhadap tenaga kerja industri pengolahan

Kabupaten Jember

\section{Kekuatan Aglomerasi}

Raw concentration menunjukan besarnya kekuatan aglomerasi pada suatu wilayah yang mendorong terjadinya konsentrasi spasial.

$$
G_{E G}=\frac{g_{E G}}{1-\sum_{i=1}^{M}(X)^{2}}
$$

Dimana:

$$
G_{E G}=\text { besarnya kekuatan aglomerasi }
$$$$
g_{E G}=\text { Indeks Gini lokasional }
$$

$X^{2}=$ Kontribusi total tenaga kerja industri pengolahan kecamatan terhadap total tenaga kerja industri

$$
\text { pengolahan Kabupaten Jember }
$$




\section{Pengaruh Eksternalitas}

Pengaruh Eksternalitas menunjukan aglomerasi yang dipengaruh oleh adanya natural advantage dan

knowledge spillover terhadap konsentrasi spasial dan industri.

$$
Y_{E G}=\frac{G_{E G}-H}{1-H}
$$

Dimana:

$$
\begin{gathered}
Y_{E G}=\text { Pengaruh Eksternalitas } \\
G_{E G}=\text { besarnya kekuatan aglomerasi } \\
\boldsymbol{H}=\text { Indeks Herfindah. }
\end{gathered}
$$

\section{Hasil dan Pembahasan}

\section{Hasil}

\section{Analisis Aglomerasi}

Konsentrasi spasial akan menciptakan keuntungan yang berupa penghematan lokalisasi dan penghematan urbanisasi yang merupakan faktor pendorong terjadinya aglomerasi. Aglomerasi dapat diukur dengan menggunakan Indeks Ellison Glaeser yang dapat dilihat pada tabel dibawah ini:

\section{Gini Lokasional}

Tabel 1. Nilai Gini Lokasional Subsektor Industri Makanan, Minuman, dan Tembakau di Wilayah Kabupaten Jember Tahun 2011-2015.

\begin{tabular}{lllllll}
\hline \multirow{2}{*}{ No } & \multirow{2}{*}{ Kecamatan } & \multicolumn{5}{c}{ Gini Lokasional } \\
\cline { 3 - 7 } & & 2011 & 2012 & 2013 & 2014 & 2015 \\
\hline 1 & Wuluhan & 0.081 & 0.080 & 0.080 & 0.082 & 0.074 \\
2 & Ambulu & 0.074 & 0.073 & 0.073 & 0.074 & 0.067 \\
3 & Rambipuji & 0.068 & 0.065 & 0.069 & 0.062 & 0.055 \\
4 & Kalisat & 0.058 & 0.057 & 0.057 & 0.058 & 0.054 \\
\hline
\end{tabular}

Sumber: Hasil analisis diolah dari data BPS 2011-2015.

Indeks gini lokasional menunjukan tingkat spesialisasi suatu sektor atau subsektor yang terkonsentrasi spasial antara beberapa wilayah. Berdasarkan tabel 1. diatas nilai gini lokasional pada kecamatan Wuluhan pada tahun 2011 sebesar 0,081 yang menunjukan adanya keanekaragaman karakteristik yang terspesialisasi antar industri pada wilayah tersebut, namun terjadi penurunan pada tahun 2015 menjadi sebesar 0,074. Selanjutnya wilayah yang terkonsentrasi kedua kecamatan Ambulu. Nilai gini lokasional sebesar 0,074 pada tahun 2011 dan mengalami penurunan menjadi 0,067 pada tahun 2015. Nilai indeks gini lokasional di kecamatan Rambipuji juga mengalami penurunan dari tahun 2011 sampai dengan tahun 2015 yaitu sebesar 0.068 menjadi 0.055. Sedangkan di Kecamatan Kalisat nilai indeks gini lokasional tidak jauh berbeda dengan Kecamatan Wuluhan, Kecamatan Ambulu dan Kecamatan Rambipuji yang menunjukan adanya penurunan keanekaragaman spesialisasi, dimana pada Kecamatan Kalisat nilai gini lokasional sebesar 0,058 pada tahun 2011 menjadi 0,054 pada tahun 2015. Penurunan ini menunjukan bahwa keanekaragaman karakteristik antar subsektor industri makanan, minuman, dan tembakau di wilayah tersebut semakin berkurang.

\section{Kekuatan Aglomerasi}

Tabel 2. Nilai Kekuatan Aglomerasi Subsektor Industri Makanan, Minuman, dan Tembakau di Wilayah Kabupaten Jember Tahun 2011-2015.

\begin{tabular}{clccccc}
\hline \multirow{2}{*}{ No } & \multirow{2}{*}{ Kecamatan } & \multicolumn{5}{c}{ Kekuatan Aglomerasi } \\
\cline { 3 - 7 } & & 2011 & 2012 & 2013 & 2014 & 2015 \\
\hline 1 & Wuluhan & 0.073 & 0.072 & 0.073 & 0.075 & 0.067 \\
2 & Ambulu & 0.072 & 0.070 & 0.071 & 0.072 & 0.065 \\
3 & Rambipuji & 0.065 & 0.063 & 0.066 & 0.059 & 0.053 \\
4 & Kalisat & 0.055 & 0.054 & 0.055 & 0.055 & 0.051 \\
\hline
\end{tabular}

Sumber: Hasil analisis diolah dari data BPS 2011-2015.

Pada Tabel 2. diatas menunjukan besarnya kekuatan aglomerasi (raw concentration) untuk melihat besarnya kekuatan aglomerasi yang terjadi pada suatu wilayah sehingga mendorong terjadinya konsentrasi spasial. Kekuatan aglomerasi yang mendorong konsentrasi spasial pada industri makanan, minuman, dan tembakau di kecamatan Wuluhan pada tahun 2011 yaitu sebesar 0,073 menjadi 0.067 pada tahun 2015. Di Kecamatan Ambulu besarnya kekuatan aglomerasi yang mendorong terjadinya konsentrasi di kecamatan tersebut sebesar 0,072 pada tahun 2011 dan mengalami penurunan pada tahun 2015 menjadi sebesar 0,065 . Selanjutnya di posisi ketiga pada kecamatan Rambipuji kekuatan aglomerasi yang mendorong terjadinya konsentrasi spasial subsektor industri makanan, minuman, dan tembakau sebesar 0.065 pada tahun 2011. Kemudian terjadi penurunan pada tahun 2015 menjadi 0.055. Hal ini diikuti oleh penurunan tingkat konsentrasi spasial yang teradi pada kecamatan Rambipuji pula. Sedangkan pada kecamatan Kalisat pada tahun 2011 yaitu sebesar 0,055 kemudian nilai yang sama juga terjadi pada tahun 2013 dan tahun 2014 Namun terjadi penurunan di kecamatan Kalisat pada tahun 2015 menjadi sebesar 0,051 .

\section{Pengaruh Eksternalitas}

Tabel 3.Pengaruh Eksternalitas Subsektor Industri Makanan, Minuman, dan Tembakau di Wilayah Kabupaten Jember Tahun 2011-2015.

\begin{tabular}{llccccc}
\hline \multirow{2}{*}{ No } & \multirow{2}{*}{ Kecamatan } & \multicolumn{5}{c}{ Pengaruh Eksternalitas } \\
\cline { 3 - 7 } & & 2011 & 2012 & 2013 & 2014 & 2015 \\
\hline 1 & Wuluhan & 0.230 & 0.219 & 0.218 & 0.231 & 0.170 \\
2 & Ambulu & 0.133 & 0.124 & 0.123 & 0.132 & 0.100 \\
3 & Rambipuji & 0.105 & 0.094 & 0.110 & 0.081 & 0.056 \\
4 & Kalisat & 0.068 & 0.064 & 0.063 & 0.068 & 0.053
\end{tabular}

Sumber: Hasil analisis diolah dari data BPS 2011-2015.

Menurut Ellison dan Glaeser industri yang terspesialisasi, konsentrasi spasial yang terjadi akibat dorongan aglomerasi disebabkan oleh adanya pengaruh eksternalitas berupa knowledge spillover dan natural advantage. Berdasarkan tabel 3. diatas pada kecamatan Wuluhan dimana nilai $\gamma_{E G}$ sebesar 0,230 pada tahun 2011 yang artinya konsentrasi spasial terjadi karena adanya pengaruh knowledge spillover dan natural advantage. Penurunan $\gamma_{E G}$ menjadi 0,170 pada tahun 2015 menunjukan penurunan eksternalitas yang disertai dari kekuatan aglomerasi. Penurunan tersebut juga diikuti oleh Kecamatan Ambulu, Kecamatan Rambipuji dan 
Kecamatan Kalisat yang mana konsentrasi spasial pada wilayah tersebut terjadi karena adanya pengaruh knowledge spillover dan natural advantage.

\section{Pembahasan}

Kecamatan Wuluhan, kecamatan Ambulu, kecamatan Rambipuji dan Kecamatan Kalisat merupakan wilayah yang memiliki nilai konsentrasi yang tinggi pada subsektor industri makanan, minuman, dan tembakau di Kabupaten Jember. Fenomena ini menunjukan bahwa subsektor industri makanan, minuman, dan tembakau terkonsentrasi di daerah Jember selatan dan Jember utara. Penentuan lokasi yang terkonsentrasi pada ke empat daerah tersebut didukung oleh teori lokasi dari Alferd Weber yang menjelaskan bahwa konsentrasi spasial suatu industri terletak pada permintaan (pasar) dan sumber bahanbaku sehingga dapat meminimalisir ongkos transportasi. Di kecamatan Wuluhan memiliki komoditas unggulan kelapa yang besar sehingga memudahkan dalam pemenuhan input pada industri gula merah. Selanjutnya di kecamatan Ambulu merupakan sentra produksi kedelai dan peternakan sapi perah. Di Kecamatan Rambipuji merupakan salah satu daerah produksi kedelai. Sedangkan di kecamatan Kalisat juga merupakan salah satu daerah produksi tanaman tembakau dan memiliki sebanyak enam gudang tembakau. Dengan ketersediaan sumber bahanbaku lokal tersebut maka pemenuhan kebutuhan input akan lebih efektif dan efisien sehingga ongkos angkut dalam pemenuhan input juga dapat diminimalisir dengan begitu juga akan mengurangi biaya produksi.

Menurut Marshal (1920) dalam pandangannya yang sering disebut dengan Marshallian Industrial Distict menjelaskan bahwa konsentrasi spasial didorong oleh ketersediaan tenaga kerja yang terspesialisasi. Dalam hal ini kecamatan Wuluhan merupakan wilayah yang paling besar menyerap tenaga kerja khususnya pada kategori subsektor industri makanan, minuman, dan tembakau yaitu sebesar 3.598 orang pada tahun 2011 dan terus mengalami peningkatan sampai pada tahun 2015 sebesar 5.570 orang dengan jumlah unit usaha sebanyak 1.257 unit pada tahun 2011 dan 1.456 unit pada tahun 2015. Selanjutnya diikuti oleh kecamatan Ambulu kecamatan Rambipuji dan kecamatan Kalisat. Selain didorong oleh ketersediaan tenaga kerja yang terspesialisasi menurut Glaeser dan Kohlase (2003) suatu industri akan terkonsentrasi pada wilayah yang cukup baik, ketersediaan infrastruktur tersebut akan memberikan kemudahan dalam mendistribusikan barang atau jasa hasil produksinya. Kecamatan Wuluhan, kecamatan Ambulu, kecamatan Rambipuji dan kecamatan Kalisat memiliki dukungan infrastruktur yang cukup baik berupa jalan raya serta sarana informasi dan telekomunikasi.

Konsentrasi spasial akan menciptakan keuntungan yang berupa penghematan lokalisasi dan penghematan urbanisasi yang merupakan faktor pendorong terjadinya aglomerasi. Penghematan lokalisasi terjadi pada industri pengolahan di kabupaten Jember, empat daerah dengan tingkat konsentrasi spasial tinggi memiliki tingkat spesialisasi pada subsektor industri makanan, minuman, dan tembakau yang tinggi pula jika dibandingkan dengan daerah lainnya. Sedangkan penghematan urbanisasi memunculkan fenomena yang disebut dengan aglomerasi yang menyebabkan terjadinya perluasan wilayah (extended regions) dan dorongan konsentrasi industri pada suatu wilayah dikabupaten Jember.
Hal ini dapat dilihat dari peningkatan jumlah tenaga kerja pada subsektor industri makanan, minuman, dan tembakau di kabupaten relatif tinggi mencapai 40.337 pekerja pada tahun 2011 dan meningkat menjadi 68.863 pekerja pada tahun 2015.

Konsentrasi spasial pada subsektor industri makanan, minuman, dan tembakau di kabupaten Jember dapat terjadi akibat adanya pengaruh aglomerasi yang disebabkan oleh upaya mengurangi biaya transportasi dengan berlokasi di sekitar local demand yang besar serta upaya untuk memperoleh akses pasar yang luas (Krugman, 1991). Wilayah yang terkonsentrasi spasial tinggi pada subsektor industri makanan, minuman, dan tembakau seperti kecamatan Wuluhan memiliki jumlah penduduk yang besar dengan kepadatan 863/km2, di ikuti oleh tiga kecamatan yaitu kecamatan Ambulu, kecamatan Rambipuji dan kecamatan Kalisat. Jumlah penduduk yang besar merupakan pangsa pasar bagi para perusahaan oleh sebab itu banyak industri yang terkonsentrasi pada keempat daerah tersebut khususnya pada kategori subsektor industri makanan, minuman, dan tembakau. Hal ini juga didukung oleh teori lokasi yang dipelopori oleh August Losch yang dikenal dengan Market Area Theory. Losch berpendapat bahwa pemilihan lokasi industri akan lebih banyak ditentukan oleh besarnya biaya angkut output produksi dan tingkat persaingan sesama produsen di pasar. Selain itu adanya pelabuhan udara di kabupaten Jember mempermudah akses menuju pasar industri tersebut, baik pasar dalam negeri maupun pasar ekspor (Dick et al, 1993). Jumlah penduduk sebagai pasar potensial dan infrastruktur transportasi (pelabuhan udara, jalan raya) yang mendukung industri merupakan natural advantage wilayah yang berperan penting dalam proses aglomerasi.

Wilayah yang terkonsentrasi spasial di Kabupaten Jember seperti kecamatan Wuluhan, kecamatan Ambulu, kecamatan Rambipuji dan kecamatan Kalisat memiliki tingkat spesialisasi yang tinggi pada subsektor industri makanan, minuman, dan tembakau. Hal ini dapat dilihat dari nilai gini lokasional pada tahun 2011-2015 dengan rata-rata di masingmasing kecamatan Wuluhan sebesar 0,079, kecamatan Ambulu sebesar 0,072 kecamatan Rambipuji sebesar 0,063 dan kecamatan Kalisat sebesar 0,057. Dengan tingkat spesialisasi yang besar pada ketiga daerah tersebut, maka akan mendorong terjadinya aglomerasi yang disebabkan oleh eksternalitas berupa tenaga kerja yang terspesialisasi, input yang terspesialisasi maupun knowledge spillover. Pada suatu industri, knowledge spillover memiliki peranan yang penting karena dengan adanya knowledge spillover akan mendorong akumulasi modal manusia yang diperkuat oleh learning by doing sehingga akan meningkatkan pertumbuhan industri tersebut (Romer, 1986; Lucas, 1988).

\section{Simpulan}

Berdasarkan analisis data yang dilakukan, maka dapat ditarik kesimpulan sebagai berikut bahwa Konsentrasi spasial yang terjadi di empat kecamatan (Wuluhan, Ambulu, Rambipuji dan Kalisat) tersebut menciptakan penghematan lokalisasi dan penghematan urbanisasi (agglomeration economies) serta mendorong pertumbuhan industri kabupaten Jember secara keseluruhan. Wilayah yang memiliki tingkat spesialisasi dan tingkat kekeuatan aglomerasi terbesar dalam mendorong 
konsentrasi spasial subsektor industri makanan, minuman, dan tembakau di Kabupaten Jember adalah kecamatan Wuluhan, kecamatan Ambulu, kecamatan Rambipuji dan kecamatan Kalisat. Perkembangan subsektor yang terkonsentrasi pada ke tiga wilayah tersebut di dorong oleh terjadinya aglomerasi yang disebabkan oleh eksternalitas berupa natural advantage dan knowledge spillover serta tenaga kerja yang terspesialisasi.

\section{Referensi}

Adisasmita, R.H. 2005. Dasar-Dasar Ekonomi Wilayah. Yogyakarta: Graha Ilmu.

Arsyad, Lincolin. 1991. Ikhtisar Teori dan Soal Jawab Ekonomi Mikro. Edisi Pertama. Yogyakarta: Penerbit BPF.

Badan Pusat Statistik. 2015. Kabupaten Jember Dalam Angka 2010-2015. Jember: BPS Kabupaten Jember

Demsetz, H. 1973. Industry Structure, Market Rivalry, and Public Policy. Journal of Law and Economics Vol. 16, issue 1, 1-9.
Dick, H. dan J. Mackie. 1993. The Economic Role of Surabaya. Proceedings of Balanced Development: East Java in the New Order. Singapore: Oxford University Press 325-343.

Ellison, G. dan Gleaser, E. 1999. Geographic Concentration of industry: Does Natural Advantage Explain Agglomeration?. American Economic Review 9: 311-316.

Fujita, M, et all. 1999. The Spatial Economy: Cities, Region, and International Trade. Cambrige and London: The MIT Press.

Kuncoro, M. 2002. Analisis Spasial dan Regional: Studi Aglomerasi dan Kluster Industri. Yogyakarta: UPP AMP YKPN.

Landiyanto, E. 2005. Konsentrasi Spasial Industri Manufaktur Tinjauan Empiris di Kota Surabaya. Jurnal Ekonomi dan Pembangunan Indonesia 5(2): 75-90.

Marshall, A. 1920. Principles of Economics. London: Mcmillan

Romer, P. 1986. Increasing Return and Long Run Growth. Journal of Political Economy. 94: 1002-1038.

Syofya, H. 2015. Konsentrasi Spasial Industri Indonesia. Jurnal Sosial dan Humaniora Vol 1, No 2.

Tarigan, R. 2005. Ekonomi Regional: Teori dan Aplikasi. Jakarta: Bumi Aksara. 